\title{
Analysis of The Implementation of The Steam Approach in Entrepreneurship Learning to Support Planning for The Implementation of Entrepreneurship Curriculum in Elementary Schools
}

\author{
Widia Indra Kartika, Rokhmaniyah \\ Universitas Sebelas Maret \\ widiaindrakartika@student.uns.ac.id
}

Article History

accepted 24/09/2019 approved 01/10/2019 published 01/12/2019

\begin{abstract}
The purpose of this study is to analyze: 1) the implementation of the STEAM approach in class IV entrepreneurship learning activities in Waluyo Kebumen State Elementary School 2, and 2) evaluation of the fourth grade entrepreneurship learning activities in Waluyo Kebumen State Elementary School 2. This research uses descriptive analytical method with a qualitative approach. Data collection techniques carried out by observation, interview, and study documentation. The results of the study include: 1) entrepreneurial learning activities with the STEAM approach in grade IV at State Elementary School 2 Waluyo Kebumen appropriate to achieve learning objectives and can foster student entrepreneurial spirit, and 2) the evaluation of entrepreneurship learning activities in class IV at Waluyo Kebumen 2 Elementary School was conducted through written tests, process assessments, and results in making products from beads and woven pandanus leaves.
\end{abstract}

Keywords: The Steam Approach, Entrepreneurship Learning, and the Entrepreneurship Curriculum

\section{Abstrak}

Tujuan penelitian ini yaitu untuk menganalisis: 1) pelaksanaan pendekatan STEAM dalam kegiatan pembelajaran kewirausahaan kelas IV di SD Negeri 2 Waluyo Kebumen, dan 2) evaluasi kegiatan pembelajaran kewirausahaan kelas IV di SD Negeri 2 Waluyo Kebumen. Penelitian ini menggunakan metode deskriptif analitis dengan pendekatan kualitatif. Teknik pengumpulan data dilakukan dengan cara observasi, wawancara, dan studi dokumentasi. Hasil penelitian meliputi: 1) kegiatan pembelajaran kewirausahaan dengan pendekatan STEAM di kelas IV di SD Negeri 2 Waluyo Kebumen sesuai untuk mencapai tujuan pembelajaran serta dapat menumbuhkan jiwa kewirausahaan siswa, dan 2) evaluasi kegiatan pembelajaran kewirausahaan kelas IV di SD Negeri 2 Waluyo Kebumen dilakukan melalui tes tertulis, penilaian proses, dan hasil dalam pembuatan produk dari manik-manik dan anyaman daun pandan.

Kata kunci: Pendekatan Steam, Pembelajaran Kewirausahaan, dan Kurikulum Kewirausahaan

Social, Humanities, and Education Studies (SHEs): Conference Series https://jurnal.uns.ac.id/shes

p-ISSN 2620-9284

e-ISSN 2620-9292 


\section{PENDAHULUAN}

Pendidikan merupakan senjata perkembangan kemajuan suatu bangsa. Dengan pendidikan akan tencipta sumber daya manusia yang berpendidikan. Menurut Subiantoro (2016) Sumber daya manusia yang berpendidikan adalah modal utama pembangunan nasional, terutama dalam bidang perekonomian bangsa. Segala tujuan pembangunan nasional akan mudah tercapai apabila banyak SDM yang berpendidikan. Pendidikan tidak hanya mampu menyelesaikan persoalan besar dalam suatu negara, akan tetapi pendidikan juga harus bisa menyelesaiakan persoalan dalam lingkup masyarakat. Hal tersebut sesuai dengan pendapat menurut Abdul Kadir (2012) yang mengatakan bahwa pendidikan sesungguhnya dijalankan untuk memenuhi kebutuhan sumber daya manusia yang minimal sanggup menghadapi persoalan lokal yang melingkupinya. Dalam Undang-Undang Dasar 1945 bahwa tujuan pendidikan adalah mencerdaskan kehidupan bangsa. Oleh karenanya, negara harus selalu memajukan elemen pendidikan dalam aspek kehidupan untuk menghasilkan SDM yang berkualitas dan kompetitif.

Setidaknya ada tiga alasan utama dari beberapa banyak alasan mengapa pendidikan harus diletakkan pada bagian yang fundamental dalam suatu bangsa. Pertama, menurut Undang-Undang Nomor 20 Tahun 2003 tentang SISDIKNAS tertuang pendidikan nasional berfungsi mengembangkan kemampuan dan membentuk watak serta peradaban bangsa yang bermartabat dalam rangka mencerdaskan kehidupan bangsa. Kedua, berdasarkan Undang-Undang Nomor 2 tahun 1989 menyatakan pendidikan nasional bertujuan untuk mencerdaskan kehidupan bangsa dan mengembangkan manusia Indonesia seutuhnya, yaitu manusia yang beriman dan bertaqwa terhadap Tuhan YME dan berbudi pekerti luhur, memiliki pengetahuan dan keterampilan, kesehatan jasmani dan rohani, berkepribadian yang mantap dan mandiri serta rasa tanggung jawab kemasyarakatan dan kebangsaan. Ketiga, Fungsi pendidikan dalam TAP MPRS Nomor XXVI/MPRS/1966 tentang Agama, pendidikan dan kebudayaan, bahwa tujuan pendidikan adalah untuk membentuk manusia Pancasila sejati berdasarkan pembukaan Undang Undang Dasar 1945.

Menurut Subiantoro (2016) Persoalan di Indonesia tidak terlepas dari pengangguran. Hal tersebut kerena peran pendidikan dalam mencetak lulusan yang umumnya lebih cenderung diarahkan untuk menjadi pencari kerja dari pada menciptakan lapangan kerja. Padahal ketimpangan antara ketersedian lapangan kerja dengan pencari kerja sangat tidak seimbang. Dari sinilah peningkatan kualitas pendidikan sanga diperlukan. Peningkatan kualitas pendidikan di Indonesia bisa dikembangkan melalui penerapan reformasi pendidikan. Perubahan yang terjadi pada pembelajaran tradisional menuju ke pembelajaran yang lebih meningkatkan daya berpikir kritis disebut dengan reformasi pendidikan (Redhana, 2010). Salah satu bentuk reformasi pendidikan dapat dilakukan dengan menggunakan pendekatan pembelajaran yang dapat membantu guru dalam menciptakan tenaga ahli yaitu pendekatan STEAM (Science, Technology, Engineering, Art and Mathematics).

Pembelajaran dengan pendekatan STEAM merupakan pembelajaran kontekstual (Yakman, 2012), dimana siswa akan diajak memahami fenomena fenomena yang terjadi yang dekat dengan dirinya. Pendekatan STEAM mendorong siswa untuk belajar mengeksplorasi semua kemampuan yang dimilikinya, dengan cara masing-masing. STEAM juga akan memunculkan karya yang berbeda dan tidak terduga dari setiap individu atau kelompoknya. Selain itu kolaborasi, kerjasama dan komunikasi akan muncul dalam proses pembelajaran karena pendekatan ini dilakukan secara berkelompok. Pengelompokan siswa dalam STEAM menuntut tanggung jawab secara personal atau interpersonal terhadap pembelajaran yang terjadi, proses ini akan membangun pemahaman siswa terhadap materi yang sedang dipelajari.

Pada proses pembelajaran guru kurang mengajak siswa untuk mengamati fenomena yang terjadi disekitarnya, atau tidak menyajikan fakta-fakta yang dekat 
dengan kehidupan siswa. Pembelajaran kurang memberikan keterkaitan, baik pada diri siswa itu sendiri atau lingkungan sekitarnya, dan guru kurang mengajak siswa untuk turut berpartisipasi dalam proses pembelajaran, sehingga siswa tidak dapat membangun pemikirannya sendiri. Siswa hanya menghafal, tidak memahami sesuatu dengan cara siswa sendiri dan bahkan dapat menemukan sendiri apa yang menjadi tujuan pembelajaran. Pengintegrasian seni dalam STEAM diharapkan mampu membuat pembelajaran lebih bermakna, karena siswa ikut terlibat dalam mewujudkan kompetensi pembelajaran yang harus dicapainya secara nyata dalam bentuk karya.

Dalam pelaksanaan pembelajaran dalam pendidikan tidak dapat lepas dari kurikulum. Menurut Karlina (2014) kurikulum adalah dokumen yang berisi tujuan pendidikan yang diharapkan, isi dari kurikulum yang berisi mata pelajaran dan lain-lain yang terkait dengan isi yang akan dilaksanakan oleh kepala sekolah, guru, siswa, dan pihak-pihak lainya, strategi dan metode pembelajaran yang digunakan, dan evaluasi yang diterapkan. Sedangkan Menurut Thaib (2015) Kurikulum merupakan jabaran materi-materi yang disajikan dalam pembelajaran, juga merupakan komponen yang sangat penting dalam suatu sistem pendidikan, kurikulum merupakan alat untuk mencapai tujuan pendidikan dan sekaligus sebagai pedoman dalam pelaksanaan pengajaran pada semua jenis dan tingkat pendidikan. Kurikulum juga berfungsi untuk memberi arahan atas segala bentuk proses pendidikan kepada pencapaian tujuantujuan pendidikan dan kurikulum bisa disebut juga sebagai perangkat lunak yang mengarahkan dan menentukan kualitas dan kuantitas produk pendidikan (Kasman, 2010).

Kurikukulum pendidikan kerap kali berganti dan disesuaikan dengan perkembangan situasi dan kondisi yang berkembang saat ini. Menurut Meiriyanti (2017) Perubahan kurikulum yang terpenting adalah bagaimana memasukan mata pelajaran yang dapat menumbuhkan jiwa kewirausahaan bagi anak didiknya. Dengan jiwa inovasi dan kreatifitas pada anak-anak bangsa akan menciptakan jiwa wirausahawan, hal itu akan dapat mendorong dan memberikan perubahan terhadap kemajuan suatu negara. Untuk itu diperlukan kurikulum pendidikan yang menunjang dalam membangun kewirausahaan.

Menurut Subiantoro (2016) Kurikulum berbasis entrepreneurship adalah kurikulum nasional yang diperkaya dengan pendidikan entrepreneurship (kewirausahaan) karena konsep pendidikan nasional terbuka untuk pengayaan. Hal ini sesuai dengan Undang-Undang No 20 tahun 2003 tentang SISDIKNAS dan Peraturan Pemerintah No 19 tahun 2005 tentang standar pendidikan nasional yang memberikan banyak ruang bagi lembaga pendidikan untuk membuat dan mengelola kurikulumnya sesuai dengan tensi dan kompetensi wilayah atau lingkungan yang dimilikinya. Menurut Suryaman (2015) Kurikulum kewirausahaan dibuat dengan konsep "belajar dan bermain", dengan tujuan akan terbentuk jiwa manusia yang menyukai perubahan, pembaharuan, kemajuan, dan tantangan..

Kurikulum berbasis kewirausahaan diharapkan dapat membekali peserta didik keterampilan soft skill dan hard skill berwirausaha dengan cara memasukkan muatan kewirausahaan baik secara substansi nilai-nilai kewirausahaan maupun aplikasinya pada setiap proses pembelajaran. Hal ini berkaitan erat dengan kurikulum yang disusun dalam sekolah guna menjawab masalah peningkatan kualitas sumber daya manusia untuk bisa bersaing diera global. Selain itu Kurikulum berbasis entrepreneurship juga diharapkan dapat menjadi kurikulum kunci yang akan menjadi ukuran keberhasilan sekolah menciptakan lulusan yang berdaya saing tinggi dipasar kerja sehingga keluaran dari pendidikan Indonesia mampu menjadi solution maker untuk bangsanya, bukan problem maker. Oleh karena itu peneliti tertarik dalam mengambil judul terkait "Analisis Pelaksanaan Pendekatan STEAM dalam 
Pembelajaran Kewirausahaan Guna Mendukung Perencanaan Penerapan Kurikulum Kewirausahaan di SD Negeri 2 Waluyo Kebumen".

Berdasarkan uraian yang dikemukakan di atas, fokus penelitian ini mengenai Analisis Pelaksanaan Pendekatan STEAM dalam Pembelajaran Kewirausahaan Guna Mendukung Perencanaan Penerapan Kurikulum Kewirausahaan di SD Negeri 2 Waluyo Kebumen. Selanjutnya dari fokus tersebut dirinci menjadi 2 (dua) subfokus yaitu, sebagai berikut: 1) pelaksanaan pendekatan STEAM dalam kegiatan pembelajaran kewirausahaan kelas IV di SD Negeri 2 Waluyo Kebumen, dan 2) evaluasi kegiatan pembelajaran kewirausahaan kelas IV di SD Negeri 2 Waluyo Kebumen.

\section{METODE}

Penelitian tentang Analisis Pelaksanaan Pendekatan STEAM dalam Pembelajaran Kewirausahaan Guna Mendukung Penerapan Kurikulum Kewirausahaan di SD Negeri 2 Waluyo Kebumen ini menggunakan metode deskriptif analitis dengan pendekatan kualitatif. Pada penelitian kualitatif, pengumpulan data dilakukan pada natural setting dan teknik pengumpulan data lebih banyak pada observasi, wawancara mendalam, dan dokumentasi (Sugiyono, 2010).

Analisis data dilakukan melalui beberapa tahap, yaitu 1) tahap pengumpulan data, 2) proses reduksi data dengan cara pengelompokkan pada data Analisis Pelaksanaan Pendekatan STEAM dalam Pembelajaran Kewirausahaan Guna Mendukung Perencanaan Penerapan Kurikulum Kewirausahaan di SD Negeri 2 Waluyo Kebumen yang telah diperoleh; 3) penyajian data dengan cara deskriptif berdasarkan aspek yang diteliti; 4) simpulan/verifikasi berdasarkan pemahaman terhadap data yang telah disajikan dan dibuat dalam pernyataan singkat yang mudah dipahami. Data primer penelitian diperoleh dari pengamatan, catatan lapangan, interview diantaranya kepada kepala sekolah dan dewan guru serta beberapa pihak yang terkait di SD Negeri Waluyo Kebumen. Data sekunder penelitian diperoleh dari perencanaan pembelajaran (RPP) dan dokumen pendukung terkait pelaksanaan pendekatan steam dalam pembelajaran kewirausahaan guna mendukung perencanaan penerapan kurikulum kewirausahaan di SD Negeri 2 Waluyo Kebumen.

\section{HASIL DAN PEMBAHASAN}

Berikut penjelasan temuan penelitian dan pembahasan mengenai Analisis Pelaksanaan Pendekatan STEAM dalam Pembelajaran Kewirausahaan Guna Mendukung Penerapan Kurikulum Kewirausahaan di SD Negeri 2 Waluyo Kebumen dengan subfokus penelitian: 1) pelaksanaan pendekatan STEAM dalam kegiatan pembelajaran kewirausahaan kelas IV di SD Negeri 2 Waluyo Kebumen, dan 2) evaluasi kegiatan pembelajaran kewirausahaan kelas IV di SD Negeri 2 Waluyo Kebumen.

1. Pelaksanaan Pendekatan Steam dalam Kegiatan Pembelajaran Kewirausahaan Kelas IV di SD Negeri 2 Waluyo Kebumen

Kegiatan pembelajaran harus disesuaikan dengan perencanaan pembelajaran yang telah dibuat guru. Dalam Permendikbud No 22 Tahun 2016 tentang Standar Proses Pendidikan Dasar dan Menengah Perencanaan pembelajaran dirancang dalam bentuk Silabus dan Rencana Pelaksanaan Pembelajaran (RPP) yang mengacu pada Standar Isi. Perencanaan Pembelajaran meliputi penyusunan rencana pelaksanaan pembelajaran dan penyiapan media dan sumber belajar, perangkat penilaian pembelajaran, dan skenario pembelajaran. Penyusunan Silabus dan RPP disesuaikan pendekatan pembelajaran yang digunakan. Berdasarkan temuan penelitian menunjukkan bahwa kegiatan pembelajaran kewirausahaan kelas IV di SD Negeri 2 Waluyo Kebumen dapat mencapai tujuan pembelajaran melalui pendekatan STEAM 
dengan kategori baik serta mampu menumbuhkan jiwa kewirausahaan siswa. Pelaksanaan kegiatan pembelajaran kewirausahaan kelas IV di SD Negeri 2 Waluyo Kebumen dimuat dari kegiatan awal, kegiatan inti, dan kegiatan penutup.

Pada kegiatan awal guru melakukan apresepsi dengan pertanyaan tentang cita-cita siswa serta pertanyaan yang mengarah pada pengertian wirausaha. Pada kegiatan inti ditemukan bahan ajar yang digunakan guru dapat menumbuhkan jiwa kewirausahaan dikarenakan berisi tentang kisah sukses wirausaha yang berasal dari Kebumen sebagai kota yang menjadi tempat tinggal siswa. Di kegiatan inti ini, siswa diajak mendengarkan kisah pengusaha sukses yang berasal dari Kebumen yang dibacakan guru kemudian siswa diajak untuk mempunyai keinginan menjadi seorang wirausaha yang sukses seperti wirausaha dalam kisah yang dibacakan guru sesuai dengan minat wirausaha yang ingin siswa nantinya capai. Dalam kegiatan inti pembelajaran guru memberikan banyak motivasi untuk menjadi pengusaha dengan mengajak siswa membuat sebuah produk. Produk yang berhasil di buat oleh siswa kelas IV antara lain benda-benda seperti kalung, gelang, tasbih dari manik-manik secara individu dan sandal dari anyaman daun pandan secara kelompok. Dalam pembelajaran membuat produk tersebut siswa diajak untuk belajar secara kooperatif, memecahkan masalah, berpikir krisis dan kreatif.

Pembelajaran dilakukan menggunakan pendekatan STEAM. Penerapan pendekatan pembelajaran ini mengintegrasikan masing-masing komponen STEAM di dalam pembelajaran berbasis proyek dengan pembuatan produk. Penerapan pendekatan STEAM juga mendorong siswa untuk memahami setiap komponen STEAM di dalam suatu pembelajaran kewirausahaan. Penerapan pembelajaran ini dilakukan dengan memberikan suatu aktivitas pembelajaran yang terdiri dari beberapa proyek didalamnya dengan mengintegrasikan komponenkomponen STEAM. Science menjelaskan tentang pengetahuan dimana dalam pembelajaran ini yaitu mengenai pemahaman konsep materi kewirausahaan. Technology menjelaskan mengenai penggunaan teknologi terbaru yang memudahkan siswa dalam pelaksanaan aktivitas seperti guru yang menggunakan laptop dalam pembelajaran dengan tampilan power point menggunakan proyektor untuk memudahkan guru menampilkan contoh-contoh karya dari manik-manik dan dari anyaman daun pandan yang nantinya dapat memunculkan kekreatifitasan siswa dalam pengerjaan produk. Engineering menjelaskan tentang teknik-teknik yang digunakan siswa selama penyelesaian proyek seperti guru menjelaskan pembuatan kalung dari manik-manik dan sandal dari ayaman daun pandan dimana peserta didik harus menyiapkan senar sesuai ukuran kalung kemudian memasukkan manik-manik sesuai urutan dari kreatifitas peserta didik serta bagaimana siswa membentuk pola pada busa ati dan anyaman daun pandan yang kemudian dijahit hingga menjadi sebuah sandal. Arts yang akan memunculkan kreatifitas siswa dalam mendesain proyek produk dari manik-manik dan anyaman daun pandan. Mathematics yang merupakan perhitungan jumlah komponen manik-manik agar tercipta produk yang unik dan menarik serta kesimetrisan ukuran tiap pasang sandal.

Dalam pelaksanaan pendekaan steam ini, guru memberikan ruang yang cukup bagi siswa untuk mandiri sesuai bakat dan minat dalam pembuatan produk dari manik-manik dan anyaman daun pandan. Kegiatan pembelajaran dengan pendekatan steam di kelas IV ini dilakukan secara interaktif antara guru dengan siswa serta menyenangkan karena peserta didik dibebaskan dalam pembuatan produk dari manik-manik dan hiasan pada sandal dari anyaman daun pandan. Pada kegiatan penutup guru menyimpulkan materi yang telah disampaikan. Guru memberikan tugas membuat produk selain dari manik-manik dan anyaman daun pandan yang dapat dijual baik makanan atau bentuk barang yang kemudian 
dikumpulkan pada pertemuan selanjutnya. Guru menutup pembelajaran dengan memberi pesan moral agar siswa mempunyai karakter wirausaha dan salam. Tujuan pembelajaran yang tercapai dalam kegiatan pembelajaran di kelas IV SD N Waluyo pada pembelajaran kewirausahaan ini adalah siswa mampu menyebutkan ciri-ciri orang sukses dengan benar, siswa mempunyai semangat menjadi wirausaha, dan siswa mampu membuat produk sesuai kreatifitasnya masingmasing.

2. Evaluasi Kegiatan Pembelajaran Kewirausahaan Kelas IV di SD Negeri 2 Waluyo Kebumen.

Menurut Permendikbud No 22 Tahun 2016 tentang Standar Proses Pendidikan Dasar dan Menengah, evaluasi proses pembelajaran dilakukan saat proses pembelajaran dengan menggunkan alat: lembar pengamatan, angket sebaya, rekaman, catatan anekdot, dan refleksi. Evaluasi kegiatan pembelajaran kewirausahaan kelas IV di SD Negeri 2 Waluyo Kebumen sudah baik. Kegiatan evaluasi dilakukan melalui tes tertulis, penilaian proses, dan hasil dalam pembuatan produk dari manik-manik dan anyaman daun pandan.

Tes tertulis berbentuk soal pilihan ganda sebanyak 15 soal. Tes tertulis masuk ke dalam penilaian kognitif. Dalam praktik pembuatan produk aspek yang dinilai yaitu penilaian sikap berupa ketekunan, disiplin, dan kemandirian. Penilaian keterampilan terdiri dari aspek kerjasama, komunikatif, kritis dan kreatif. Kemudian penilaian Portofolio Asesoris yang terdiri dari aspek kerapihan dan keindahan serta kreativitas.

Penerapan pendekatan STEAM dalam pembelajaran kewirausahaan sangat mendukung usaha SD $\mathrm{N} 2$ Waluyo dalam merencanakan penerapan kurikulum kewirausahaan. Latar belakang perencanaan kurikulum kewirausahaan SD N 2 Waluyo adalah tantangan menghadapi era 21 dimana siswa dituntut untuk mandiri. Hal tersebut sesuai dengan pendapat Hadinugrahaningsih (2017: 31) bahwa penerapan pendekatan STEAM dalam pembelajaran sangat sesuai dengan keterampilan abad 21 yang terbagi ke dalam 3 kategori besar yaitu keterampilan belajar dan berinovasi, keterampilan menggunakan informasi, media dan teknologi, serta keterampilan hidup dan berkarir. Kedepannya dari pihak sekolah menurut kepala sekolah dan guru SD N 2 Waluyo akan menjalankan kurikulum kewirausahaan. Dengan kurikulum kewirausahaan ini akan adanya pendidikan kewirausahaan yang nantinya akan berdiri sendiri dan diterapkan di kelas IV, V, dan VI. Akan tetapi menurut kepala sekolah dan guru SD N 2 Waluyo dengan adanya pendidikan kewirausahaan yang berdiri sendiri akan menambah jam mata pelajaran dimana nantinya harus direncanakan lebih matang lagi.

\section{SIMPULAN}

Berdasarkan hasil penelitian yang telah dilakukan dapat disimpulkan bahwa penerapan pendekatan STEAM dalam pembelajaran kewirausahaan sangat mendukung usaha SD $\mathrm{N} 2$ Waluyo dalam merencanakan penerapan kurikulum kewirausahaan melalui 1) kegiatan pembelajaran kewirausahaan dengan pendekatan STEAM di kelas IV di SD Negeri 2 Waluyo Kebumen yang sesuai untuk mencapai tujuan pembelajaran kewirausahaan serta dapat menumbuhkan jiwa kewirausahaan siswa, dan 2) evaluasi kegiatan pembelajaran kewirausahaan kelas IV di SD Negeri 2 Waluyo Kebumen yang dilakukan melalui tes tertulis, penilaian proses, dan hasil dalam pembuatan produk dari manik-manik dan anyaman daun pandan.

\section{DAFTAR PUSTAKA}

Abdul Kadir. (2012). Upaya Meningkatkan Life Skill Peserta Didik Melalui Pendekatan Sains Teknologi Masyarakat dalam Pembelajaran IPA. Skripsi. STAIN Sultan Qaimudin Kendari. 
Hadinugrahaningsih, dkk. (2017). Keterampilan Abad 21 Dan Steam (Science, Technology, Engineering, Art And Mathematics) Project Dalam Pembelajaran Kimia. Jakarta: LPPM Universitas Negeri Jakarta.

Karlina, E \& Eswandi. (2014). Analisis Pembelajaran Mata Pelajaran Prakarya Dan Kewirausahaan Dengan Menggunakan Kurikulum 2013 Di Sman 46 Jakarta. Research and Development Journal Of Education Vol. 1, No.01.

Kasman. (2010). Improvisasi Manajemen Kurikulum dan Pembelajaran Sekolah Bermutu. Jurnal Manajemen Pendidikan Vol. 23, No. 2, Hal 121-128.

Meiriyanti, R, dan Santoso, A. (2017). Implementasi Kurikulum Berbasis Entrepreneurship Untuk Mencetak Generasi Pengusaha Dalam Menghadapi Bonus Demografi. Jurnal Ekonomi Vol. 12, No. 2, Hal 1-21.

Peraturan Pemerintah No 19 Tahun 2005 Tentang Standar Pendidikan Nasional.

Permendikbud No 22 Tahun 2016 Tentang Standar Proses Pendidikan Dasar dan Menengah.

Redhana, I W. (2010). Pengaruh Model Pembelajaran Berbasis Peta Argumen terhadap Keterampilan Berpikir Kritis Siswa pada Topik Laju Reaksi. Jurnal Pendidikan dan Pengajaran Vol. 43, No. 17, Hal 141-148.

Subiantoro, M.D \& Karwanto. (2016). Manajemen Kurikulum Berbasis Entrepreneurship Di Sma Muhammadiyah 9 Surabaya. Jurnal Dinamika Manajemen Pendidikan Vol. 1, No. 1, Hal. 55-67

Sugiyono. (2010). Metodologi Penelitian Kualitatif \& RND. Bandung: Alfabeta.

Suryaman. (2015). Model Kurikulum Berbasis Wirausaha sebagai Upaya Penguatan Pendidikan Berbasis Multibudaya di Sekolah Dasar. Jurnal Pendidikan Sains Sosial dan Kemanusiaan Vol. 8, No.1.

TAP MPRS No XXVI/MPRS/1966.

Thaib, R.M, dan Siswanto, I. (2015). Inovasi Kurikulum Dalam Pengembangan Pendidikan. Jurnal Edukasi, Vol.1, No. 2.

Undang-Undang Dasar 1945.

Undang-Undang No 2 Tahun 1989 Tentang Sistem Pendidikan Nasional.

Undang-Undang No 20 Tahun 2003 Tentang Sistem Pendidikan Nasional.

Undang-Undang No 28 Tahun 2003 Tentang Sistem Pendidikan Nasional.

Yakman, Georgette., Hyongyong, Lee. C. (2012). Exploring The Exemplary STEAM Education in the U.S. as a Practical Educational Framework for Korea. J Korea Assoc. Sci. Edu. Vol. 32, No. 6. 